\title{
Evaluation of Breeding Bulls for Age at First Calving and First Lactation Milk Yield Based on Performance of their Progeny
}

\author{
G. Prakash*, K. Anilkumar and V. Jamuna \\ Department of Animal Genetics and Breeding, \\ College of Veterinary and Animal Sciences, Mannuthy-680 651, \\ Kerala Veterinary and Animal Sciences University, Kerala, India \\ *Corresponding author
}

\section{A B S T R A C T}

Keywords

Field progeny testing, Age at first calving, First lactation milk yield

Article Info

Accepted:

12 March 2020

Available Online:

10 April 2020
The present study was carried out to find the level of performance of crossbred bulls based on AFC and FLMY of their progenies under the field condition. The data of progenies of 128 crossbred bulls from three different sources BAIF, Pune, GADVASU, Ludhiana and PDC, Meerut formed the experimental units over the period of last 10 year (2006 to 2016). The bulls were placed in three groups based on their exotic inheritance and grouped into seven batches based on period at their use. Analysis of data of 743 progeny of age at first calving and 617 progenies for first lactation milk yield using General Linear Model of SPSS version 21 software was done. There is no significant effect of exotic inheritance of bulls on traits under study. Significant difference between progenies of bulls for AFC and FLMY was noticed. The annual genetic gain during the study is reduction of 9.85 days in AFC and increasing of $81.54 \mathrm{~kg}$ in FLMY. It indicates progressive genetic improvement for AFC and FLMY through field progeny testing in crossbred cattle of Kerala.

\section{Introduction}

Indian is an agricultural country so crop and livestock production play a major role for rural farmer economy and development of our nation. Then it gives employment to millions of rural farmers, as well as major source of income throughout the year. India is number one in milk production it is indicate that one of the world fastest growing country for milk and it's byproduct productions is concern. The overall contribution of Livestock Sector in total GDP is nearly $4.11 \%$ at current prices during 2012-13.

Milk is food for each species of infants not only in infants in adults also. Its leads to huge demand for milk and its product, so meet out such a demand we want to select genetically superior animal for milk production in our 
future. Nearly about 70 percent of the population is engaged in agriculture and rearing of livestock. As per the $19^{\text {th }}$ All India Livestock Census (2012), the total livestock population in the country is 512.05 million Numbers out of which $37.28 \%$ are cattle. India has 190.90 million cattle out of which 33060 thousands are crossbreds. The number of crossbred cattle has increased during 2012 as compared to 2007 (33060 to 39732 thousands).

In Kerala also crossbred population is 1251.58 thousands were as indigenous population only account for 77.05 thousands. Kerala state produce 2654.70 thousand tonnes of milk out of which 2483.31 thousand tonnes from crossbred and only 2.08 thousand tonnes from our indigenous cattle.

Crossbred cattle are the dairy animals of Kerala as crossbreeding was accepted as the breeding policy for genetic improvement of dairy cattle in the state. As a result more than 95\% of total cattle populations of Kerala are crossbreds. Improvements in productivity of these animals are bought out through use of superior bulls. Field Progeny Testing (FPT) is a tool for selection of genetically superior bulls based on production performance of their progenies.

Performance of crossbred bulls is being evaluated in different agro-climatic zones of the country through Indian Council of Agricultural Research (ICAR) sponsored filed progeny testing programme. The present study was aimed to evaluate the performance of progenies of bulls used for progeny testing for last ten years in Kerala.

\section{Materials and Methods}

The milk yield data and pedigree information were collected from the history sheets and milk record registers of ICAR-Field Progeny
Testing Scheme, Kerala. The records on Age at first calving and first lactation 305-day or less milk yields of 743 and 617crossbred progenies sired by 128 bulls spread over a period of 16 years (2006-2016) were collected.

The progenies of 128 bulls of three different sources namely 26 bulls of Bharatheeya Agro Industries Federation, Pune (BAIF), 24 bulls of Guru Angad Dev Veterinary and Animal Sciences University, Ludhiana (GADVASU) and 78 bulls of Project Directorate on Cattle, Meerut were the experimental units for this study. These progenies were produced from the semen of the bulls through artificial insemination in field units Avannur, Chempankandam, Chuvannumannu, Marottichal, Chirakkakode and Ayyappankavu

Bulls were grouped into three genetic groups based on exotic inheritance as group 1, having $50 \%$ or less than $50 \%$ exotic inheritance, group 2 having $50 \%$ to $62.5 \%$ inheritance and group 3 with bulls of exotic inheritance between $62.5 \%$ to $75 \%$. Bulls were grouped into seven batches based on period of use of their semen as batch 5 to batch 11 serially numbered.

The information on artificial insemination, pregnancy diagnosis and calving are recorded on the progenies of the experimental bulls through persons of field units. Age at First Calving (AFC) was recorded as the number of days between date of birth of the progeny to date of its first calving.

First Lactation Milk Yield (FLMY) was calculated from monthly test day milk yields (Kg) of the progenies. The data over the period of last 10 years from 2006 to 2016 on 743 progenies were analyzed for age at first calving (Table 1) and 617 progenies were used for first lactation milk yield (Table 2). 
Mixed model analysis of data was carried out by General Linear Model and Duncan multiple range test by using SPSS version 21 to study the effects of genetic group and batch on age at first calving and first lactation milk yield records of crossbred cattle of Kerala. Then genetic gain also calculated based on standard method to find out genetic improvement.

\section{Results and Discussion}

\section{Age at first calving}

The age at first calving ranged from 918.26 days in batch 11 to 1359.7 days in batch 7 as shown in the Figure 1. Annual genetic gain of age at first calving was calculated for the period as 9.85 days (Table 5).

\section{First lactation milk yield}

The first lactation milk yields of progenies of different sets are depicted in Figure 2. It has increased from $2272.83 \mathrm{Kg}$ in batch no 5 to $3087.81 \mathrm{Kg}$ in batch no 11 . Annual genetic gain for the period in milk yield was calculated as $81.54 \mathrm{~kg}$ (Table 4).

\section{Effect of exotic inheritance}

The average AFC and FLMY of progenies of different genetic groups of bulls are presented. There was no statistically significant effect of genetic group of bulls on age at first calving and first lactation milk yield of progeny (Table 3).

\section{Effect of batch of the bull}

The average AFC and FLMY of progenies of different batches of bulls are presented. There was statistically significant effect of genetic group of bulls on age at first calving and first lactation milk yield of progenies.
The results clearly indicate that there is no significant difference between the progenies based on exotic inheritance of bull in age at first calving and first lactation milk yield. The result indicates that there is no advantage on increasing the exotic inheritance of breeding bulls beyond 50\%. The higher exotic inheritance of bulls can lead to problems with disease resistance and heat susceptibility.

Age at first calving of the progenies of $11^{\text {th }}$ batch of bulls was significantly lower than the previous batch. Lower AFC is an economically important trait as the returns from the cow can be achieved earlier. Furthermore number of calvings during life time is also directly linked with AFC. Hence it is clear that the $11^{\text {th }}$ batches of bulls are having advantage over previous batches of bulls.

The FLMY of progenies of the $11^{\text {th }}$ batch of bulls was significantly higher than that of all other previous batches of bulls indicating the higher genetic worth of these bulls compared with the previous batches. The average of 3087. $81 \pm 157.76$ is higher the average production of crossbred cows of Kerala (Economic Review, 2017)

Correlation between age at first calving and milk yield was reported by Pirlo, G et al., 2000. Nilforooshan, M.A., et al., 2004 reported that AFC significantly affect many of the traits like milk yield, fat yield, fat percentage, lifetime, and productive life in our investigation also AFC having effect on FLMY.

In our investigation level of exotic inheritance of sire had no significant effect on first lactation milk yield whereas Khan et al., (2008), Lakshmi et al., (2009) reported that sire group had significant effect on milk yield. Garcha and Dev (1994) and Singh et al., (2007) in crossbred cattle observed that the 
age at first calving had significant effect on 305-day milk yield. Chacko and Jose (1988) reported that age at first calving and first lactation milk yield in crossbred cattle of Kerala was 28 to 32 months and 2300 to 2 $700 \mathrm{~kg}$ respectively.

Naicy Thomas and Anilkumar (2009) reported average 305 days milk yield in University Livestock Farm, Mannuthy and Cattle Breeding Farm, Thumburmuzhi was $2070.5 \pm 59.1 \mathrm{~kg}$. in our study average first lactation milk yield in crossbred cattle in Kerala was $3087.81 \mathrm{~kg}$. It indicates progressive genetic improvement for AFC and FLMY through field progeny testing in crossbred cattle of Kerala.

Kokate et al., 2013also observed that the average 305-day or less milk yield was $3068 \pm 23 \mathrm{~kg}$ with coefficient of variation $25.3 \%$ in Karan Fries cattle.

Singh (2006) also observed that the average 305-day milk yield was $3197 \pm 43 \mathrm{~kg}$ with coefficient of variation $24.98 \%$ in Karan Fries cattle.

Manvendra Singh et al., 2016 reported that the average first lactation 305 days or less milk yield (FL305DMY) was 1806.45 \pm 16.99 with coefficient of variation 29.21\%in Murrah buffaloes.

In our results clearly indicates that non genetic factors influencing age at first calving and first lactation milk yield. Different field center and years having significance different on age at first calving and first lactation milk yield. Among the six field centers and period Chuvannumannu and 2016 having higher first lactation milk yield and age at first calving is concern Ayyappankavu and 2016 had lower age at first calving. Banu et al., (2012) in Karan Fries cows reported that nonsignificant effect of period of calving on first lactation 305day milk yield (Fig. 3-6; Table 6 and 7).

Table.1 Number of progenies recorded for AFC and FLMY per genetic group wise

\begin{tabular}{|c|c|c|}
\hline Genetic Group & $\begin{array}{c}\text { No. progenies having AFC } \\
\text { records }\end{array}$ & $\begin{array}{c}\text { No. progenies having } \\
\text { FLMY records }\end{array}$ \\
\hline $\mathbf{1}$ & 74 & 64 \\
\hline $\mathbf{2}$ & 18 & 15 \\
\hline $\mathbf{3}$ & 651 & 538 \\
\hline Total & 743 & 617 \\
\hline
\end{tabular}

Table. 2 Number of progenies recorded for AFC and FLMY per genetic group wise

\begin{tabular}{|c|c|c|}
\hline Batch & $\begin{array}{c}\text { No. progenies having AFC } \\
\text { records }\end{array}$ & $\begin{array}{c}\text { No. progenies having FLMY } \\
\text { records }\end{array}$ \\
\hline $\mathbf{5}$ & 58 & 56 \\
\hline $\mathbf{6}$ & 120 & 117 \\
\hline $\mathbf{7}$ & 93 & 84 \\
\hline $\mathbf{8}$ & 127 & 97 \\
\hline $\mathbf{9}$ & 66 & 52 \\
\hline $\mathbf{1 0}$ & 123 & 99 \\
\hline $\mathbf{1 1}$ & 156 & 112 \\
\hline Total & 743 & 617 \\
\hline
\end{tabular}


Table.3 Effect of exotic inheritance of bull on AFC and FLMY of crossbred cattle of Kerala

\begin{tabular}{|c|c|c|c|}
\hline Genetic group & Exotic inheritance of bulls & AFC (days) & FLMY (kg) \\
\hline $\mathbf{1}$ & Below 50\% & 1034.85 & 2560.47 \\
\hline $\mathbf{2}$ & $50 \%$ to 62.5\% & 1118.52 & 2460.34 \\
\hline $\mathbf{3}$ & $62.5 \%$ to $75 \%$ & 1091.54 & 2578.59 \\
\hline
\end{tabular}

Note: Mean having common superscripts shows no significant difference within a column.

Table.4 Effect of batch of sire on AFC and FLMY of crossbred cattle of Kerala

\begin{tabular}{|c|c|c|}
\hline Batch & Progenies AFC in days & Progenies FLMY in kg \\
\hline $\mathbf{5}$ & $1016.78^{\mathrm{bc}}$ & $2272.33^{\mathrm{c}}$ \\
\hline $\mathbf{6}$ & $1043.08^{\mathrm{bc}}$ & $2354.31^{\mathrm{c}}$ \\
\hline $\mathbf{7}$ & $1359.70^{\mathrm{a}}$ & $2439.86^{\mathrm{bc}}$ \\
\hline $\mathbf{8}$ & $1089.16^{\mathrm{bc}}$ & $2451.94^{\mathrm{bc}}$ \\
\hline $\mathbf{9}$ & $997.49^{\mathrm{bc}}$ & $2429.21^{\mathrm{bc}}$ \\
\hline $\mathbf{1 0}$ & $1146.26^{\mathrm{b}}$ & $2693.67^{\mathrm{b}}$ \\
\hline $\mathbf{1 1}$ & $918.26^{\mathrm{c}}$ & $3087.81^{\mathrm{a}}$ \\
\hline
\end{tabular}

Note: Mean having different superscripts shows significant difference within a column

Table.5 Genetic gain in AFC and FLMY of progenies between the batches of bulls

\begin{tabular}{|c|c|c|}
\hline Batch No. & Genetic gain for AFC in days & Genetic gain for FLMY in kg \\
\hline $\mathbf{5}$ to 6 & 2.63 & 8.19 \\
\hline $\mathbf{6}$ to 7 & 31.66 & 8.55 \\
\hline $\mathbf{7}$ to 8 & -27.05 & 1.20 \\
\hline $\mathbf{8}$ to 9 & -9.16 & -2.27 \\
\hline $\mathbf{9}$ to 10 & 14.95 & 26.44 \\
\hline $\mathbf{1 0}$ to 11 & -22.87 & 39.41 \\
\hline Over all 2006 to 2016 & 9.85 per year & 81.54 per year \\
\hline
\end{tabular}

Table.6 AFC and FLMY of progenies between the years

\begin{tabular}{|c|c|c|}
\hline Period & AFC in days & FLMY in kg \\
\hline $\mathbf{2 0 0 6}$ & $1063^{\mathrm{ab}}$ & $2182^{\mathrm{a}}$ \\
\hline $\mathbf{2 0 0 7}$ & $1120^{\mathrm{bc}}$ & $2395 \mathrm{~b}^{\mathrm{c}}$ \\
\hline $\mathbf{2 0 0 8}$ & $1156^{\mathrm{c}}$ & $2362^{\mathrm{ab}}$ \\
\hline $\mathbf{2 0 0 9}$ & $1034^{\mathrm{ab}}$ & $2319^{\mathrm{ab}}$ \\
\hline $\mathbf{2 0 1 0}$ & $1093^{\mathrm{abc}}$ & $2285^{\mathrm{ab}}$ \\
\hline $\mathbf{2 0 1 1}$ & $1103^{\mathrm{abc}}$ & $2651^{\mathrm{de}}$ \\
\hline $\mathbf{2 0 1 2}$ & $1093^{\mathrm{abc}}$ & $2710^{\mathrm{def}}$ \\
\hline $\mathbf{2 0 1 3}$ & $1038^{\mathrm{ab}}$ & $2546^{\mathrm{cd}}$ \\
\hline $\mathbf{2 0 1 4}$ & $1017^{\mathrm{a}}$ & $2772^{\mathrm{ef}}$ \\
\hline $\mathbf{2 0 1 5}$ & $1023^{\mathrm{a}}$ & $2783^{\mathrm{ef}}$ \\
\hline $\mathbf{2 0 1 6}$ & $1016^{\mathrm{a}}$ & $2848^{\mathrm{f}}$ \\
\hline
\end{tabular}

Note: Mean having different superscripts shows significant difference within a column 
Table.7 AFC and FLMY of progenies between the field centers

\begin{tabular}{|c|c|c|}
\hline Field centers & AFC in days & FLMY in kg \\
\hline Ayyappankavu & $955^{\mathrm{a}}$ & $2603^{\mathrm{bc}}$ \\
\hline Avannur & $991^{\mathrm{ab}}$ & $2673^{\mathrm{c}}$ \\
\hline Chempankandam & $1046^{\mathrm{bc}}$ & $2646^{\mathrm{bc}}$ \\
\hline Chuvannumannu & $1158^{\mathrm{d}}$ & $2711^{\mathrm{c}}$ \\
\hline Chirakkakode & $1068^{\mathrm{c}}$ & $2401^{\mathrm{a}}$ \\
\hline Marottichal & $1094^{\mathrm{c}}$ & $2524^{\mathrm{ab}}$ \\
\hline
\end{tabular}

Note: Mean having different superscripts shows significant difference within a column

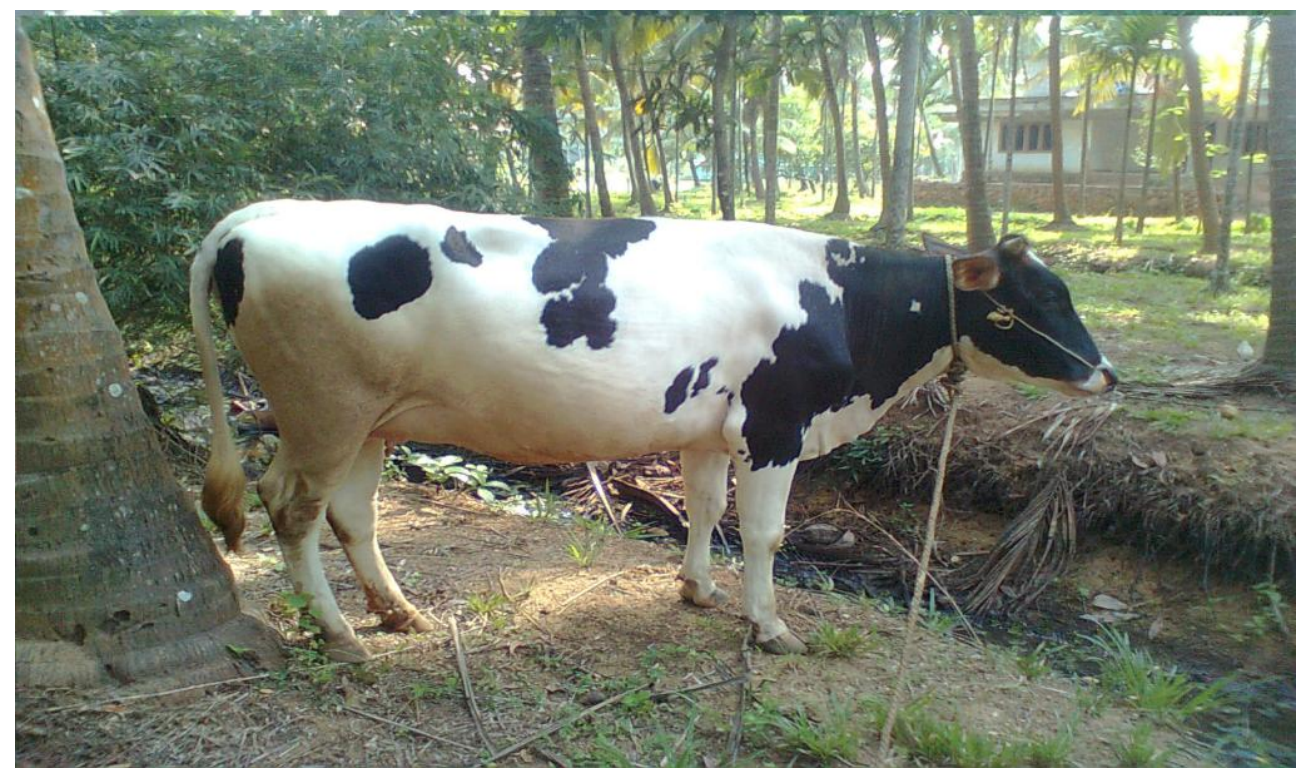

Picture.1 Progeny for ICAR-FPT, Kerala

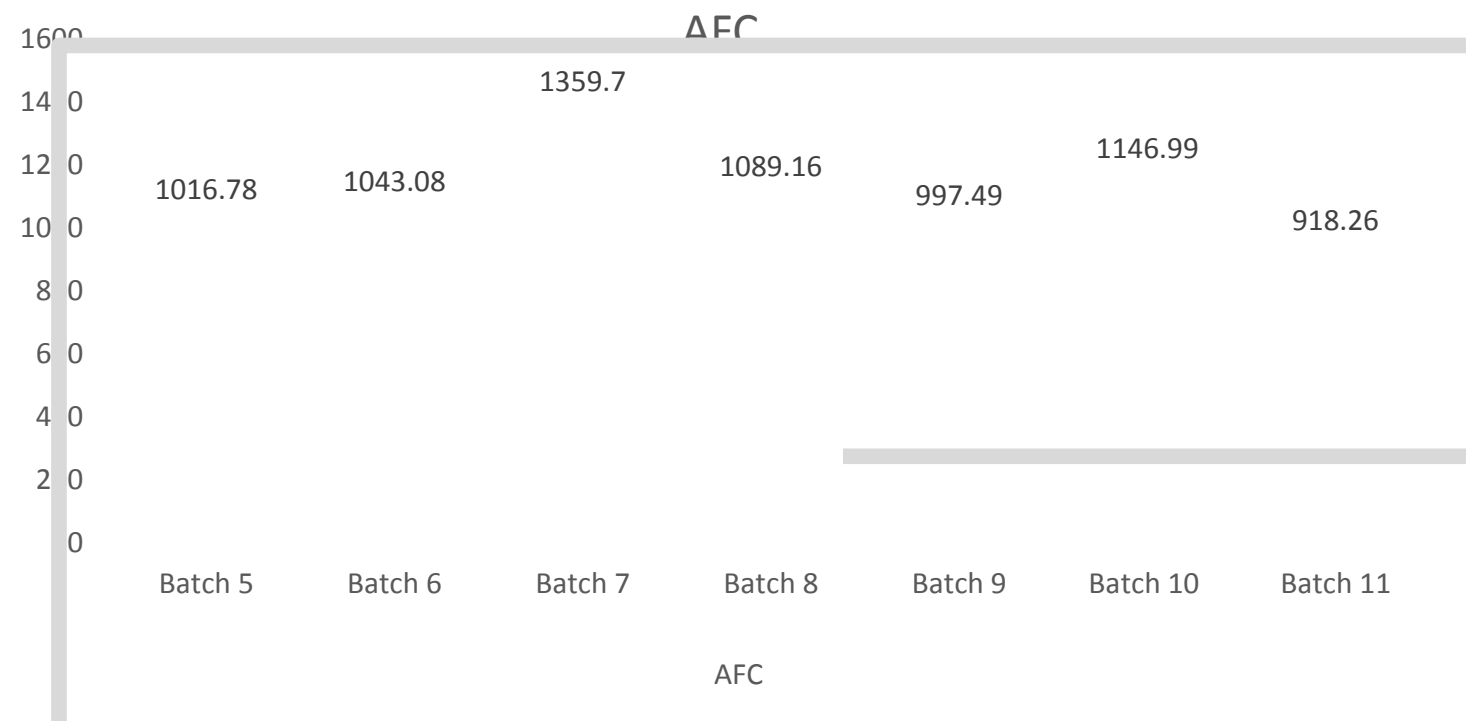

Fig.1 Age at first calving of progenies of different batches of bulls 


\section{E I n V V}

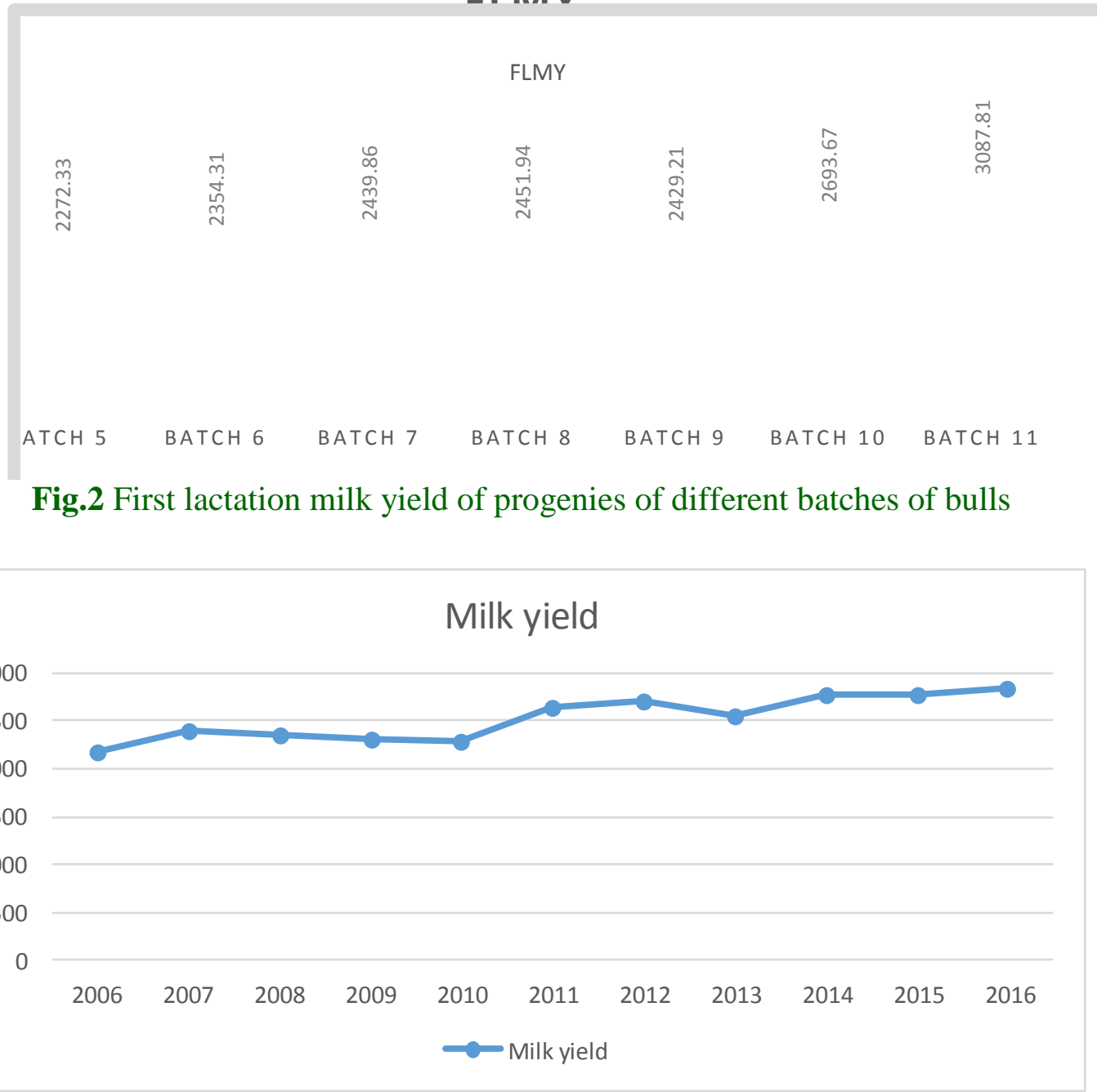

Fig.3 First lactation milk yield of progenies of different years

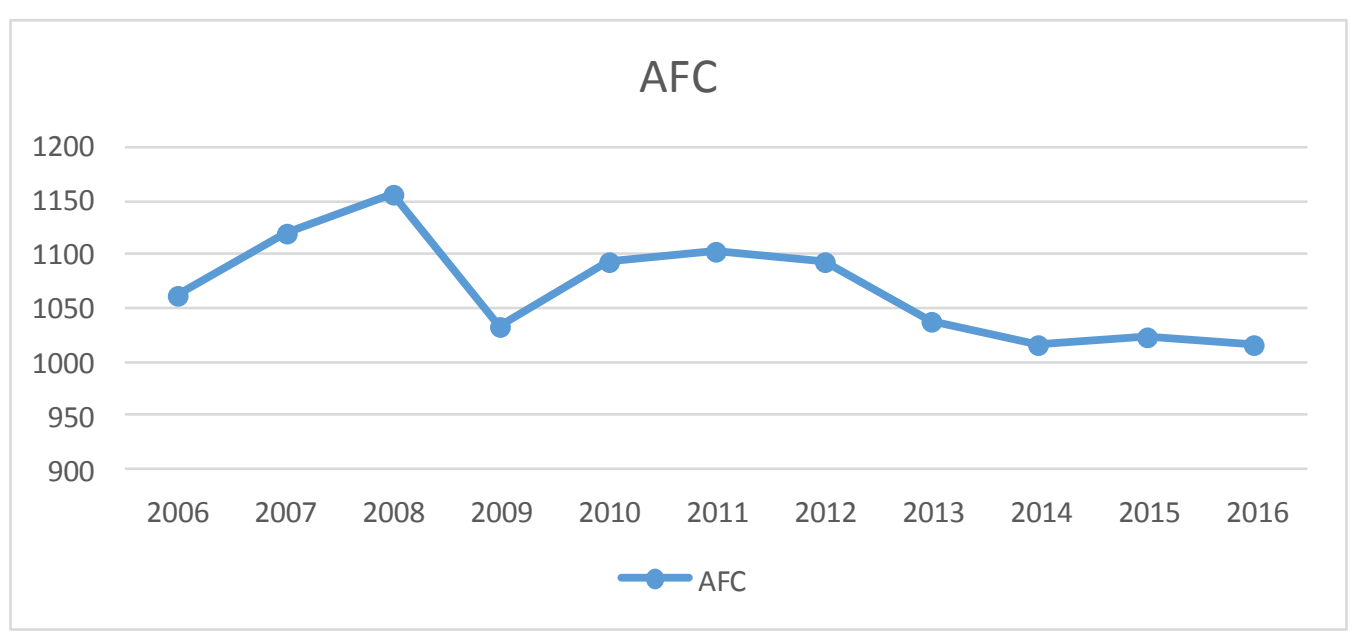

Fig.4 First lactation milk yield of progenies of different years 


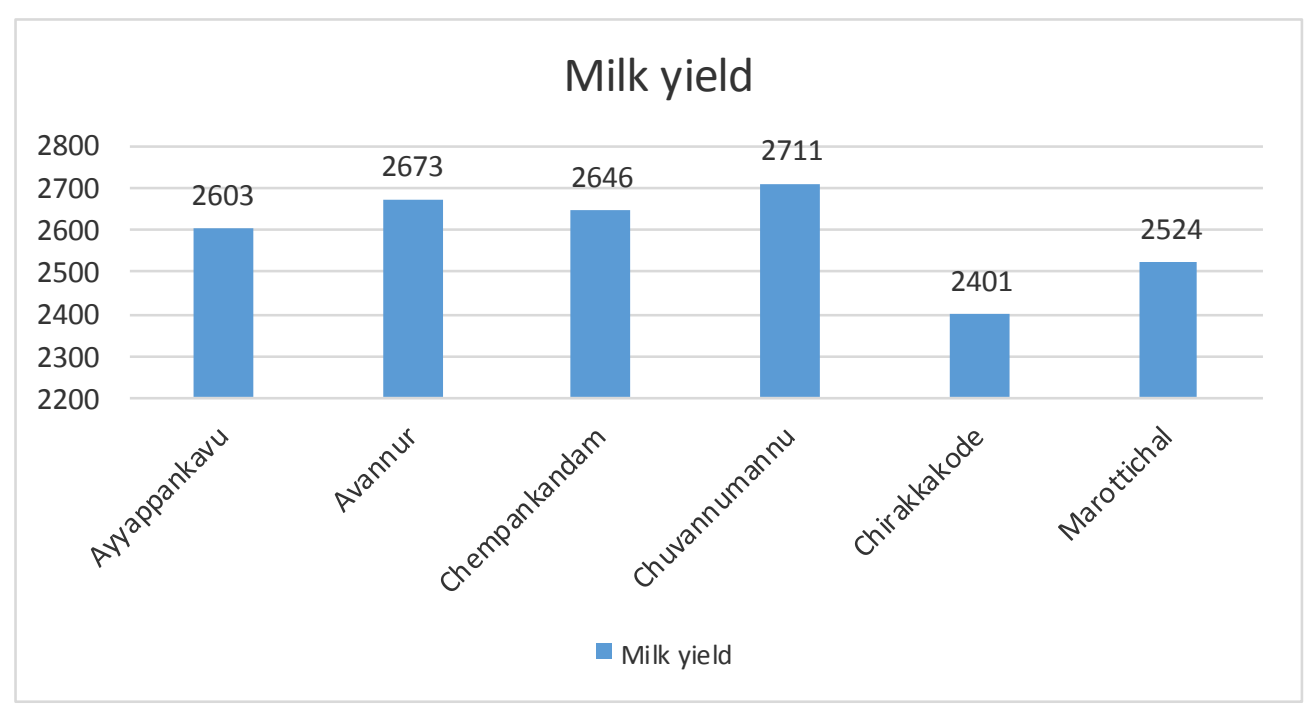

Fig.5 First lactation milk yield of progenies of different years

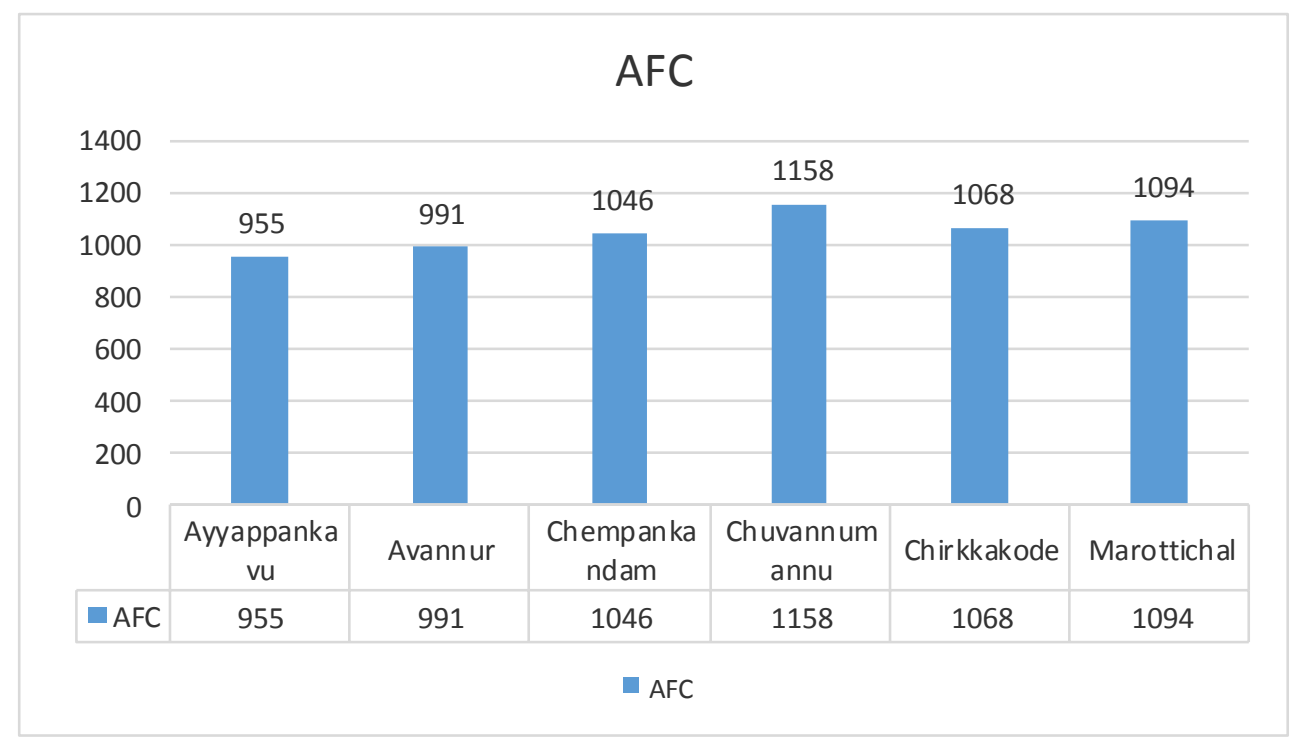

Fig.6 First lactation milk yield of progenies of different years

Genetic improvement in age at first calving and milk yield can be achieved by Crossbreeding instead of going selective breeding of native breed of Kerala (Vechur).

Because compare to vechur production and reproduction parameters crossbred having two fold higher production performance and vechur population very low so we cannot go for selection of animal with high accuracy and consequences of inbreeding was high so as per Kerala native breed population and climatic factors is concern crossbreeding always superior for genetic improvement in age at first calving and milk yield.

\section{Acknowledgments}

The author gratefully acknowledges The Director, Centre for Advanced Studies in Animal Genetics and Breeding, for giving permission for publication of this article. The 
authors like to place on record the gratitude to Dr Sunanda C, Assistant Professor, Department of Statistics, CVAS Mannuthy for helping in analysis of the results of the study.

\section{References}

Anonymous; Annual report 2016 on ICAR field progeny testing scheme, Kerala Veterinary and Animal Sciences University, Mannuthy Unit.

Chacko, C.T. \& Jose, T.K. 1988. Crossbreeding for milk production enhancement in Kerala. Indian Dairyman, 40: 697-709

Das, A.K., Ravinder Kumar, Rathee, S.K., Anilkumar, K., Radhika, G. and Prakesh, B. 2017. Genetic improvement of HF-crossbred in kerala under field progeny teting project [abstract]. In: compendium, National symposium on Biodynamic animal farming for the management of livestock diversity under changing global scenario; $8^{\text {th }}$ to $10^{\text {th }}$ February, 2017, Mannuthy. Kerala Veterinary and Animal Sciences University.P. 145. Abstract No. MTY 396.

Economic Survey, 2016-17, Government of India, Ministry of Finance Department of Economic Affairs Economic Division, January, 2017.

Garcha, D.S. and Dev, D.S. 1994. Factors affecting milk yield performance of crossbred cattle under field conditions of Punjab. J. Dairying, Food and Home Sci. 13: 48-52.

Khan, M. S., Bilal, G., Bajwa, I. R., Rehman, Z. And Ahmad, S. 2008. Estimation ofbreeding values of sahiwal cattle using test day Milk yields.Pakist. Vet. J.,28(3): 131-135.

Lakshmi, B.S., Gupta, B.R., Sudhakar, K., Prakash, M.G. and Sharma, S. 2009. Genetic analysis of production performance of Holstein Friesian $\times$ Sahiwal cows. TamilNadu J. Vet. Ani. Sci.,5 (4): 143-148.

Naicy Thomas and Anilkumar, K. 2009. Evaluation of Ten Sire Families of Crossbred Dairy Cattle of Kerala Based on Milk Production and Milk Composition Traits. Vet. Wld., 2(1): 1012.

Nilforooshan, M.A. and Edriss, M.A. 2004. Effect of Age at First Calving on Some Productive and Longevity Traits in Iranian Holsteins of the Isfahan Province. . J. Dairy Sci., 87 (7): 2130 2135.

Pirlo, G., Miglior, F. and Speroni, M. 2000. Effect of Age at First Calving on Production Traits and on Difference Between Milk Yield Returns and Rearing Costs in Italian Holsteins. J. Dairy Sci., 83 (3): 603 - 608.

Singh, Avtar, Singh, B. and Haile, A. 2007. Genetic and environmental factors influencing first lactation part and 305 day milk production in Karan Fries cattle. Indian J. Anim. Sci., 77 (11): 1151-1154.

Singh, D.V. 2017. Tenets for the success of progeny testing program under Indian field conditions. In: Singh, D.V. (ed.), proceedings of XIII National conference of ISAGB conference; $19^{\text {th }}$ to 20 $0^{\text {th }}$ January, 2017, ICAR-IVRI, Izatnagar. pp. 124-129.

\section{How to cite this article:}

Prakash, G., K. Anilkumar and Jamuna, V. 2020. Evaluation of Breeding Bulls for Age at First Calving and First Lactation Milk Yield Based on Performance of their Progeny. Int.J.Curr.Microbiol.App.Sci. 9(04): 1503-1511. doi: https://doi.org/10.20546/ijcmas.2020.904.177 